\title{
Confirming anthropogenic influences on the major organic and inorganic constituents of rainwater in an urban area
}

\author{
K. Chon ${ }^{1,2}$, Y. Kim ${ }^{3}$, D. H. Bae ${ }^{4}$, and J. Cho ${ }^{5}$ \\ ${ }^{1}$ Department of Civil and Environmental Engineering, Yonsei University, Yonsei-ro 50, Seoul 120-749, Korea \\ ${ }^{2}$ Chemical Safety Division, National Institute of Agricultural Science, 166, Nongsaengmyeong-ro, Iseo-myeon, \\ Wanju-gun, Jeollabuk-do, 565-851, Korea \\ ${ }^{3}$ School of Environmental Science and Engineering, Gwangju Institute of Science and Technology (GIST), 123 \\ Cheomdangwagi-ro, Buk-gu, Gwangju 500-712, Korea \\ ${ }^{4}$ Department of Civil and Environmental Engineering, Sejong University, Neungdong-ro 209, Gwangjin-gu, \\ Seoul 143-747, Korea \\ ${ }^{5}$ School of Urban and Environmental Engineering, Ulsan Institute of Science and Technology (UNIST), \\ UNIST-gil 50, Ulsan 689-798, Korea \\ Correspondence to: J. Cho (jaeweoncho@unist.ac.kr)
}

Received: 5 April 2015 - Published in Drink. Water Eng. Sci. Discuss.: 25 June 2015

Revised: 2 October 2015 - Accepted: 19 October 2015 - Published: 3 November 2015

\begin{abstract}
Recently, rainwater composition affected by atmospheric pollutants has been the topic of intense study in East Asia because of its adverse environmental and human health effects. In the present study, the chemical composition and organic compounds of rainwater were investigated from June to December 2012 at Gwangju in Korea. The aim of this study is to determine the seasonal variation of rainwater chemical composition and to identify possible sources of inorganic and organic compounds. The volumeweighted mean of $\mathrm{pH}$ ranged from 3.83 to 8.90 with an average of 5.78 . Of rainwater samples, $50 \%$ had $\mathrm{pH}$ values below 5.6. The volume-weighted mean concentration (VWMC) of major ions followed the order $\mathrm{Cl}^{-}>\mathrm{SO}_{4}^{2-}>\mathrm{NH}_{4}^{+}>\mathrm{Na}^{+}>\mathrm{NO}_{3}^{-}>\mathrm{Ca}^{2+}>\mathrm{Mg}^{2+}>\mathrm{K}^{+}$. The VWMC of trace metals decreased in the order $\mathrm{Zn}>\mathrm{Al}>\mathrm{Fe}>\mathrm{Mn}>\mathrm{Pb}>\mathrm{Cu}>\mathrm{Ni}>\mathrm{Cd}>\mathrm{Cr}$. The VWMCs of major ions and trace metals were higher in winter than in summer. The high enrichment factors indicate that $\mathrm{Zn}, \mathrm{Pb}, \mathrm{Cu}$, and $\mathrm{Cd}$ originated predominantly from anthropogenic sources. Factor analysis (principal component analysis) indicates the influence of anthropogenic pollutants, sea salt, and crustal materials on the chemical compositions of rainwater. Benzoic acids, $1 \mathrm{H}$-isoindole1,3(2H)-dione, phthalic anhydride, benzene, acetic acids, 1,2-benzenedicarboxylic acids, benzonitrile, acetaldehyde, and acetamide were the most prominent pyrolysis fragments for rainwater organic compounds identified by pyrolysis gas chromatography/mass spectrometry (Py-GC/MS). The results indicate that anthropogenic sources are the most important factors affecting the organic composition of rainwater in an urban area.
\end{abstract}




\section{Introduction}

Rain is an efficient scavenging process for pollutants in the air and is becoming a source of pollution to the environment (Santos et al., 2011). The emission of $\mathrm{SO}_{2}$ and $\mathrm{NO}_{x}$ from fossil fuel combustion and industrial processes has rapidly increased in East Asia due to its fast growing economy. These gases are converted into sulfuric and nitric acids before precipitating as acid rain (Lee et al., 2000; Báez et al., 2006). Consequently, there have been adverse environmental effects on aquatic, biological, and terrestrial systems (Bard, 1999; Başak and Alagha, 2004). Thus, the chemical composition of precipitation has been investigated all around the world during the last decade (Lara et al., 2001; Mouli et al., 2010; Santos et al., 2011).

Coal combustion, automobile exhaust, and industrial emissions represent the dominant anthropogenic sources of heavy metals in rainwater (Kaya and Tuncel, 1997; Hu and Balasubarmanian, 2003; Cheng et al., 2011). Heavy metals from precipitation accumulate in the biosphere and may cause adverse human health and environmental effects (Barrie et al., 1987; Báez et al., 2007). Thus, the studies of heavy metals in rainwater have increased in many countries (Pike and Moran, 2001; Al-Momani, 2003; Báez et al., 2007).

Dissolved organic carbon (DOC) is a major component of both continental $(161 \mu \mathrm{M})$ and marine rain $(23 \mu \mathrm{M})$ (Willey et al., 2000). DOC is a mixture of simple substances such as alkanes, carbohydrates, and fatty acids, and of complex polymeric molecules, such as aromatic, aliphatic, and carboxylic carbons (Muller et al., 2008). Rainwater DOC plays a significant role in the atmospheric carbon cycle, and the global rainwater flux of DOC is $430 \times 10^{12} \mathrm{~g} \mathrm{C} \mathrm{yr}^{-1}$ (Willey et al., 2000). Sources of DOC compounds in rainwater are primary anthropogenic and biogenic emissions, and photochemical transformations of precursors (Klouda et al., 1996). While numerous studies have been conducted on the inorganic chemistry of rainwater, little attention has been paid to organic compounds. Kawamura et al. (1983) initiated the identification and distribution of organic compounds in rainwater. The role of organic compounds in atmospheric processes has gained much attention in the last few years, and knowledge of organic compounds has improved with various analytical methods (Kieber et al., 2002; Seitzinger et al., 2003). However, the organic compounds in the atmosphere are very complicated and chemical characterization of organic matter in precipitation requires further work (Santos et al., 2009).

Several studies have examined chemical composition of rainwater in Korea. Although many studies have been conducted on the seasonal variation of all the major ions or heavy metals in rainwater (Lee et al., 2000; Kang et al., 2004; Kim et al., 2012; Moon et al., 2012), there are few on the organic compounds and the sources and variation of DOC in precipitation (Yan and Kim, 2012).
In this study, rainwater samples were collected from June to December 2012 in an urban area of Gwangju, Korea. The objectives of this study are to investigate the seasonal variation of rainwater chemical composition and to identify possible sources of inorganic and organic compounds in rainwater.

Our framework for research design is as follows:

1. seasonal variation in chemical composition (ions and trace metals) of rainwater

2. enrichment factor analysis to evaluate the contribution of non-crustal sources

3. variation in chemical composition of initial and subsequent rainfall

4. factor analysis to investigate the influence of natural and anthropogenic sources

5. analysis of organic compounds in rainwater.

\section{Materials and methods}

\subsection{Study site}

Rainwater samples were collected at the Gwangju Institute

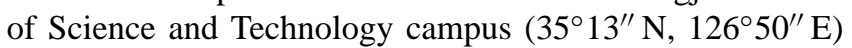
in Gwangju, Korea (Fig. 1), from June to December in 2012. Gwangju has an area of $501.34 \mathrm{~km}^{2}$ and a population of around 1480000 . The annual average temperature is $13.5^{\circ} \mathrm{C}$ and the average precipitation is $1368 \mathrm{~mm}$ per year.

\subsection{Sample collection and analysis}

Rainwater samples were collected per event using a Tefloncoated collector designed to manually take samples with time. Samples from initial precipitation events were collected with care not to be mixed with later precipitation samples. Initial rainwater samples were collected from a single rain event or multiple rain events in a single day. We collected initial rainwater samples until a $2 \mathrm{~L}$ glass jar was filled during the beginning of the rain event. All the initial and later samples were transported to the laboratory and $\mathrm{pH}$ and electrical conductivity (EC) were measured. The remaining samples were filtered through $0.45 \mu \mathrm{m}$ filters (mixed cellulose ester, Advantec, Japan) and then stored at $4{ }^{\circ} \mathrm{C}$ until further chemical analyses were performed within 1 week. $\mathrm{pH}$ and $\mathrm{EC}$ were measured using a $\mathrm{pH}$ meter and an EC meter, respectively (Orion 3-Star, Thermo Scientific, USA).

Major ions were quantified using a suppressed type ion chromatograph (DX-120, ICS-90, Dionex, Sunnyvale, CA, USA). An IonPac AS14 and an IonPac CS12A column (Dionex, Sunnyvale, CA, USA) were used for measurements of major anions $\left(\mathrm{NO}_{3}^{-}, \mathrm{SO}_{4}^{2-}\right.$, and $\left.\mathrm{Cl}^{-}\right)$and cations $\left(\mathrm{NH}_{4}^{+}\right.$, $\mathrm{Ca}^{2+}, \mathrm{Mg}^{2+}, \mathrm{Na}^{+}$, and $\mathrm{K}^{+}$), respectively. The concentrations of trace metals were measured using inductively coupled plasma mass spectrometry (ICP-MS) (7500ce, Agilent, 


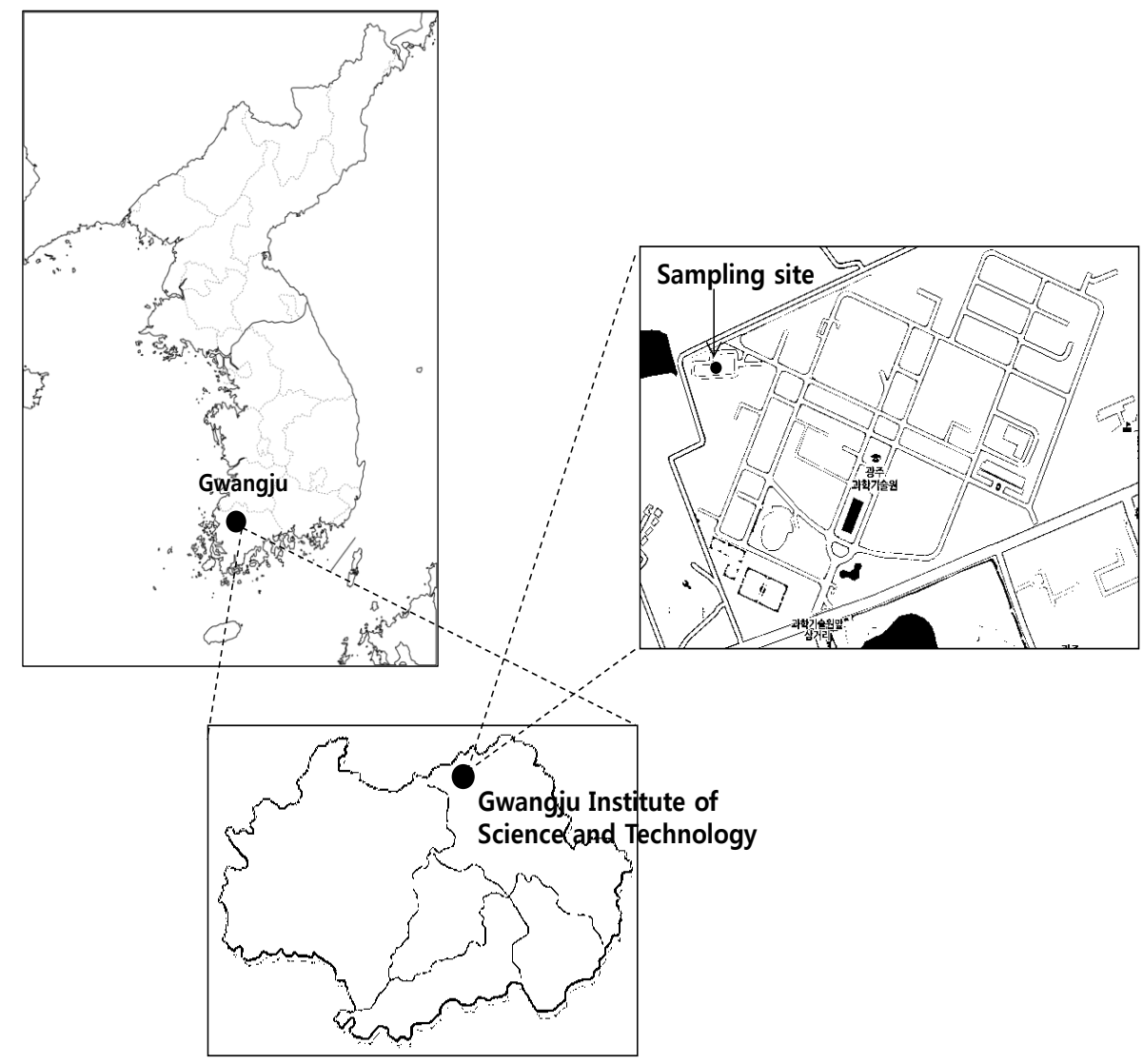

Figure 1. Location of the sampling site for this study.

Santa Clara, CA, USA). All the samples were acidified to a final nitric acid concentration of $2 \%$ using a $70 \%$ nitric acid solution. The levels of DOC and total nitrogen (TN) contents of rainwater samples were determined using a total organic carbon analyzer (TOC-V CPH, Shimadzu, Japan) equipped with a TN analyzer (TNM-1, Shimadzu, Japan). The UV absorbance of the samples at $254 \mathrm{~nm}\left(\mathrm{UV}_{254}\right)$ was measured using a UV-vis spectrophotometer (UV-1601, Shimadzu, Japan). The specific UV absorbance (SUVA) value (an indicator of aromaticity) was calculated from the ratio of $\mathrm{UV}_{254}$ to DOC concentration. Rainwater samples were concentrated to a final DOC concentration of approximately $100 \mathrm{mg} \mathrm{C} \mathrm{L}^{-1}$ with a rotary evaporator (Eyela, Japan). Approximately $20 \mathrm{~mL}$ of concentrated samples was freeze-dried using a freeze dryer (Ilshin, Korea) prior to pyrolysis gas chromatography/mass spectrometry (Py-GC/MS) analysis. Approximately $0.5-1.0 \mathrm{mg}$ of freeze-dried sample powders were pyrolyzed at $590{ }^{\circ} \mathrm{C}$ for $5 \mathrm{~s}$ in the pyrofoil (Pyrofoil F590, Japan Analytical Industry, Tokyo, Japan) within a Curie point pyrolyzer (JCI-22, Japan Analytical Industry, Tokyo, Japan) coupled with an Agilent 7890A gas chromatograph coupled to a $5975 \mathrm{C}$ quadrupole mass spectrometer (ion source temperature $220^{\circ} \mathrm{C}$, scanning from 40 to $500 \mathrm{amu}$, electron energy $70 \mathrm{eV}$ ). Pyrolysis fragments were separated by GC equipped with a DB-5MS (Agilent Technologies, USA) column and identified using a mass spectrometer. Helium was used as the carrier gas. The temperature program of the GC oven was initially maintained at $40{ }^{\circ} \mathrm{C}$ for $5 \mathrm{~min}$, then increased at $7{ }^{\circ} \mathrm{C} \mathrm{min}^{-1}$ to a final temperature of $300^{\circ} \mathrm{C}$ and remained there for $10 \mathrm{~min}$, giving a total run time of $52.14 \mathrm{~min}$. The interpretation of the pyrochromatograms was conducted according to the methods described in Bruchet et al. (1990).

\section{Results and discussion}

\subsection{Variation of $\mathrm{pH}$ value and precipitation amount}

The average monthly rainfall from June to December during 2012 was $195.4 \mathrm{~mm}$ and the highest amount of rainfall $(473.5 \mathrm{~mm}$ ) was observed in August 2012 (Fig. 2). Of the total rainfall, $79 \%$ occurred during the summer (JulySeptember). The percent frequency distribution of $\mathrm{pH}$ for the rainwater samples is presented in Fig. 3. The volumeweighted mean of $\mathrm{pH}$ was 5.78 . The lowest $\mathrm{pH}$ value was observed on 11 July with a $\mathrm{pH}$ of 3.83 , while the highest was on 22 August 2012 with a $\mathrm{pH}$ value of 8.90. Most $\mathrm{pH}$ values ranged between 5.0 and $5.5(23.9 \%)$, while about $2.6 \%$ 


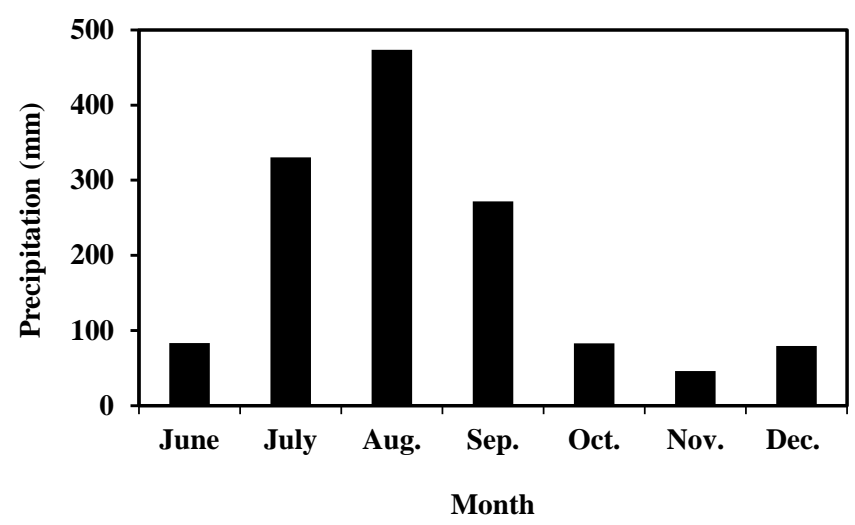

Figure 2. Monthly integrated precipitation at Gwangju during 2012.

of $\mathrm{pH}$ values were in the range of 3.5-4.5. Of the samples, $50 \%$ had $\mathrm{pH}$ values below 5.6, which is the value of unpolluted water equilibrated with atmospheric $\mathrm{CO}_{2}$ (Charlson and Rodhe, 1982). On the other hand, approximately $12 \%$ of the samples had a $\mathrm{pH}$ above 7.0, suggesting strong inputs of alkaline substances to rainwater in this area.

\subsection{Ionic composition of rainwater}

The volume-weighted mean concentration (VWMC), standard deviation of the VWMC (SDVWMC), and minimum (Min) and maximum (Max) concentrations of the rainwater chemical components are summarized in Table 1. VWMC was calculated by the following equation:

$\mathrm{VWMC}=\sum_{i=1}^{n} X i P i / \sum_{i=1}^{n} P i$,

where $X i$ is the measured ion concentration, $P i$ is the precipitation amount, and $n$ is the number of samples. The VWMC of major ions in rainwater follows the order $\mathrm{Cl}^{-}>\mathrm{SO}_{4}^{2-}>\mathrm{NH}_{4}^{+}>\mathrm{Na}^{+}>\mathrm{NO}_{3}^{-}>\mathrm{Ca}^{2+}>\mathrm{Mg}^{2+}>\mathrm{K}^{+}$. Among all the ions, $\mathrm{Cl}^{-}$was the most abundant with an average of $123.5 \mu \mathrm{eq} \mathrm{L}^{-1}$, accounting for $28.5 \%$ of the ionic concentration. $\mathrm{SO}_{4}^{2-}$ was the second highest anion with an average of $91.9 \mu \mathrm{eq} \mathrm{L}^{-1}$, accounting for $21.2 \%$ of total ions. The contribution of $\mathrm{NO}_{3}$ was $8.5 \%$ (concentration of $36.8 \mu \mathrm{eq} \mathrm{L}^{-1}$ ). The high value of $\mathrm{SO}_{4}^{2-}$ and highest of $\mathrm{Cl}^{-}$ can be attributed to emissions from fossil fuel combustion and typhoons and sea salts, respectively. As for cation species, $\mathrm{NH}_{4}^{+}$made the highest contribution at $63.0 \mu \mathrm{eq} \mathrm{L} \mathrm{L}^{-1}$, accounting for $14.5 \%$ of the total ions. Meanwhile, $\mathrm{Na}^{+}$ was the second highest cation accounting for $13.5 \%$ of the total ions. The concentration of $\mathrm{Ca}^{2+}, \mathrm{Mg}^{2+}$, and $\mathrm{K}^{+}$ions accounted for $8.5,3.5$, and $1.8 \%$, respectively. The high level of $\mathrm{NH}_{4}^{+}$in Gwangju was comparable to Seoul (with a mean concentration of $66.4 \mu \mathrm{eq} \mathrm{L}^{-1}$; Lee et al., 2000). Wastes from agricultural and domestic activities as well as

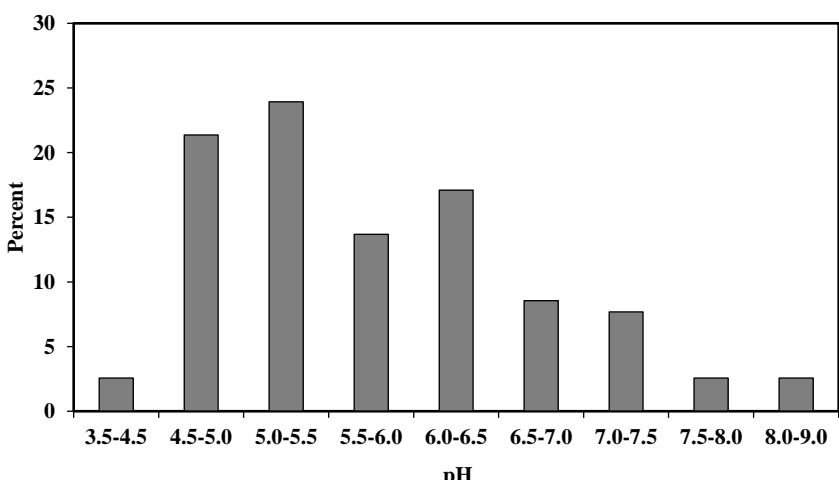

pH

Figure 3. Distribution of $\mathrm{pH}$ in rainwater samples collected from Gwangju.

the use of fertilizers are believed to be the main sources of the emission of gaseous ammonia (Dianwu and Anpu, 1994; Panyakapo and Onchang, 2008). $\mathrm{Ca}^{2+}$ may originate from wind-blown dust and calcareous soil, $\mathrm{Mg}^{2+}$ from sea salts and dusts in the atmosphere, while $\mathrm{Na}^{+}$from sea salts. EC of rainwater ranged from 0.87 to $169.00 \mu \mathrm{S} \mathrm{cm}^{-1}$, with a VWM (volume-weighted mean) value of $27.82 \mu \mathrm{S} \mathrm{cm}^{-1}$. The VWMs of UV and SUVA in rainwater were 0.0160 and 1.09 , respectively. Organic matter in rainwaters exhibit relatively hydrophilic characteristics, with SUVA values less than 2 generally indicating a high fraction of hydrophilic non-humic matter with low UV absorbance.

The VWMC of major ions in rainwater at Gwangju were compared to those reported in other urban areas around the world (Table 2). The $\mathrm{pH}$ value measured in our study is lower than that in Tirupati, India, but higher than those reported for other sites. The concentration of $\mathrm{Na}^{+}$is comparable to that in Shanghai but lower than in Istanbul and higher than other areas. The $\mathrm{Cl}^{-}$value is comparable to that in Istanbul and much higher than those reported for other sites. The high concentration of marine elements was likely due to typhoons during summer seasons. The value of $\mathrm{NO}_{3}^{-}$is higher than that in southeastern Brazil and close to that in other sites. Regarding $\mathrm{SO}_{4}^{2-}$, its concentration is higher than that in Seoul, Mexico, and Brazil and lower than in other areas. Shanghai shows the highest values of $\mathrm{NO}_{3}^{-}$and $\mathrm{SO}_{4}^{2-}$, indicating severe air pollution problems in China. Both of these ions were mainly derived from the high coal/fuel consumption and mobile sources. The concentrations of $\mathrm{K}^{+}, \mathrm{Ca}^{2+}$, and $\mathrm{Mg}^{2+}$ are higher than those in Seoul, Mexico, and Brazil and lower than in other sites. The concentrations of these ions are comparatively higher in Istanbul than in other areas. The value of $\mathrm{NH}_{4}^{+}$is comparable to that in Seoul and higher than that in India, Turkey, and Brazil.

\subsection{Seasonal variation}

Figure 4 displays the monthly variation of $\mathrm{VWM}$ of $\mathrm{pH}$, conductivity, TOC, TN, SUVA, and UV of rainwater sam- 
Table 1. Volume-weighted mean concentration (VWMC), standard deviation of the VWMC (SDVWMC), and minimum (Min) and maximum (Max) concentrations of chemical composition in rainwater collected from June to December during 2012.

\begin{tabular}{|c|c|c|c|c|c|}
\hline$n=113$ & & VWMC & SDVWMC & Min & Max \\
\hline $\mathrm{pH}$ & & 5.78 & 1.66 & 3.83 & 8.90 \\
\hline Conductivity & $\mu \mathrm{Scm}^{-1}$ & 27.82 & 11.13 & 0.87 & 169.00 \\
\hline TOC & $\mathrm{mgCL}^{-1}$ & 1.49 & 0.53 & 0.15 & 6.90 \\
\hline UV & $\mathrm{cm}^{-1}$ & 0.0160 & 0.0061 & 0.0006 & 0.0972 \\
\hline SUVA & & 1.09 & 0.30 & 0.03 & 2.42 \\
\hline TN & $\mathrm{mg} \mathrm{NL}^{-1}$ & 1.13 & 0.40 & N.D. & 8.62 \\
\hline \multirow[t]{2}{*}{$\mathrm{Na}^{+}$} & $\mathrm{mg} \mathrm{L}^{-1}$ & 1.4 & 0.7 & 0.0 & 19.65 \\
\hline & $\mu e q L^{-1}$ & 58.5 & 30.7 & 1.2 & 854.50 \\
\hline \multirow[t]{2}{*}{$\mathrm{NH}_{4}^{+}$} & $\mathrm{mg} \mathrm{L}^{-1}$ & 1.1 & 0.4 & 0.0 & 5.9 \\
\hline & $\mu \mathrm{eq} \mathrm{L}^{-1}$ & 63.0 & 22.1 & 1.6 & 327.1 \\
\hline \multirow[t]{2}{*}{$\mathrm{K}^{+}$} & $\mathrm{mg} \mathrm{L}^{-1}$ & 0.3 & 0.1 & 0.0 & 1.9 \\
\hline & $\mu e q \mathrm{~L}^{-1}$ & 7.7 & 4.1 & 0.3 & 53.0 \\
\hline \multirow[t]{2}{*}{$\mathrm{Mg}^{2+}$} & $\mathrm{mg} \mathrm{L}^{-1}$ & 0.2 & 0.1 & N.D. & 2.5 \\
\hline & $\mu e q \mathrm{~L}^{-1}$ & 15.3 & 7.5 & N.D. & 208.6 \\
\hline \multirow[t]{2}{*}{$\mathrm{Ca}^{2+}$} & $\mathrm{mg} \mathrm{L}^{-1}$ & 0.7 & 0.4 & N.D. & 6.7 \\
\hline & $\mu e q L^{-1}$ & 36.7 & 17.7 & N.D. & 337.1 \\
\hline \multirow[t]{2}{*}{$\mathrm{NO}_{3}^{-}$} & $\mathrm{mg} \mathrm{L}^{-1}$ & 2.28 & 0.9 & N.D. & 12.4 \\
\hline & $\mu e q \mathrm{~L}^{-1}$ & 36.8 & 14.8 & N.D. & 199.2 \\
\hline \multirow[t]{2}{*}{$\mathrm{SO}_{4}^{2-}$} & $\mathrm{mg} \mathrm{L}^{-1}$ & 4.4 & 2.1 & 0.0 & 19.5 \\
\hline & $\mu e q \mathrm{~L}^{-1}$ & 91.9 & 42.6 & 0.9 & 405.4 \\
\hline \multirow[t]{2}{*}{$\mathrm{Cl}^{-}$} & $\mathrm{mg} \mathrm{L}^{-1}$ & 4.4 & 3.0 & 0.0 & 39.3 \\
\hline & $\mu \mathrm{eq} \mathrm{L}^{-1}$ & 123.5 & 83.7 & 1.0 & 1106.4 \\
\hline
\end{tabular}

N.D.: not detected, $n$ : number of samples. WHO (World Health Organization) drinking water guidelines: $\mathrm{pH}: 6.5-8.5, \mathrm{NH}_{4}^{+}: 1.5 \mathrm{mg} \mathrm{L}^{-1}, \mathrm{NO}_{3}^{-}: 50 \mathrm{mg} \mathrm{L}^{-1}, \mathrm{SO}_{4}^{2-}: 250 \mathrm{mg} \mathrm{L}^{-1}, \mathrm{Cl}^{-}$: $250 \mathrm{mg} \mathrm{L}^{-1}$.

Table 2. Comparison between the VWMC of major ions $\left(\mu \mathrm{eq} \mathrm{L}^{-1}\right)$ in precipitation in Gwangju and at other sites.

\begin{tabular}{|c|c|c|c|c|c|c|c|c|c|c|c|}
\hline Location & Period & $\mathrm{pH}$ & $\mathrm{Na}^{+}$ & $\mathrm{NH}_{4}^{+}$ & $\mathrm{K}^{+}$ & $\mathrm{Mg}^{2+}$ & $\mathrm{Ca}^{2+}$ & $\mathrm{NO}_{3}^{-}$ & $\mathrm{SO}_{4}^{2-}$ & $\mathrm{Cl}^{-}$ & References \\
\hline This study & June-Dec. 2012 & 5.78 & 58.5 & 63.0 & 7.7 & 15.3 & 36.7 & 36.8 & 91.9 & 123.5 & \\
\hline Seoul, Korea & May 1996-Apr. 1998 & 4.7 & 10.5 & 66.4 & 3.5 & 6.9 & 10.5 & 29.9 & 70.9 & 18.2 & Lee et al. (2000) \\
\hline Tirupati, India & July 2000-June 2001 & 6.78 & 33.08 & 20.37 & 33.89 & 50.51 & 150.66 & 40.84 & 127.96 & 33.91 & Mouli et al. (2005) \\
\hline Istanbul, Turkey & Oct. 2001-July 2002 & 4.81 & 75.2 & 12.8 & 57.4 & 99.6 & 285 & 33.4 & 115.2 & 124.8 & Basak and Alagha (2004) \\
\hline Mexico City, Mexico & May 2001-Oct. 2002 & 5.08 & 7 & 92.35 & 2.16 & 2.46 & 26.44 & 42.62 & 61.94 & 9.56 & Baez et al. (2007) \\
\hline Shanghai, China & 2005 & 4.49 & 50.11 & 80.68 & 14.89 & 29.64 & 203.98 & 49.8 & 199.59 & 58.34 & Huang et al. (2008) \\
\hline Piracicaba, southeastern Brazil & Aug. 1997-July 1998 & 4.5 & 2.7 & 17.1 & 2.9 & 2.3 & 5.3 & 16.6 & 18.7 & 7 & Lara et al. (2001) \\
\hline
\end{tabular}

ples. $\mathrm{pH}$ values measured during summer seasons (JuneSeptember) with greater rainfall were higher than those during the winter season (October-December). This is consistent with previous studies (Cerón et al., 2013). Lee et al. (2000) also mentioned that the amount of rainfall influences $\mathrm{pH}$. Conductivity values increased from summer to winter seasons, in agreement with the seasonal trend of major ions. Lower conductivity during the summer was caused by the dilution effect of higher rainfall. The values of TOC show similar monthly trends to $\mathrm{TN}$, increasing with decreasing rainfall amounts. Similar seasonal variations of TOC have been reported in other studies (Pan et al., 2010; Yan and Kim, 2012). DOC in the atmosphere is known to vary with the seasons due to biogenic emission form vegetation. Kieber et al. (2002) reported relatively higher levels of DOC in rainwater in warmer seasons; in contrast, Yan and Kim (2012) indicated that it was due to the prevailing anthropogenic contributions (mostly fossil fuel burning) and low precipitation in the relatively dry winter season. They also found that DOC in precipitation over Seoul was mainly produced by incomplete combustion of fossil fuel. The values of TN display similar monthly trends with TOC. They were higher in spring, fall, and winter, which are relatively dryer than summer. As expected, this is consistent with the monthly variation of $\mathrm{NO}_{3}^{-}$ and $\mathrm{NH}_{4}^{+}$. The value of $\mathrm{UV}_{254}$ measured during the winter season (November-December) is higher than in the summer season (July-September). SUVA values higher than 1.4 were measured in September, November, and December, but in the 

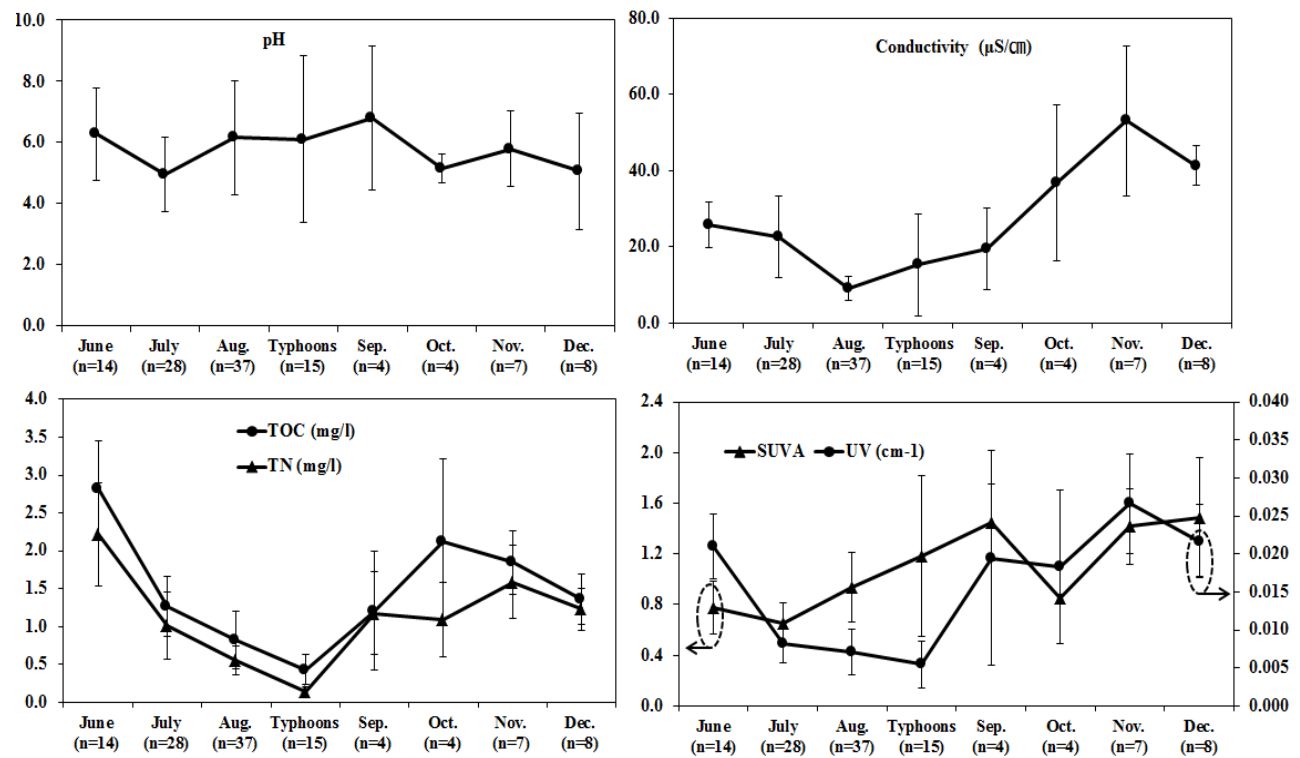

Figure 4. Monthly variation of the volume-weighted mean value of $\mathrm{pH}$, conductivity, TOC, TN, SUVA, and UV absorbance in rainwater samples collected in Gwangju during 2012.

Table 3. Correlation matrix between ions in rainwater samples. The Pearson correlation coefficient and the $P$ values are shown. Bold numbers presents $R^{2}>0.6$.

\begin{tabular}{llllllll}
\hline Variables & $\mathrm{Na}^{+}$ & $\mathrm{NH}_{4}^{+}$ & $\mathrm{K}^{+}$ & $\mathrm{Mg}^{2+}$ & $\mathrm{Ca}^{2+}$ & $\mathrm{NO}_{3}^{-}$ & $\mathrm{Cl}^{-}$ \\
\hline $\mathrm{NH}_{4}^{+}$ & 0.19 & & & & & & \\
& 0.04 & & & & & & \\
$\mathrm{~K}^{+}$ & 0.50 & 0.50 & & & & & \\
& 0.00 & 0.00 & & & & & \\
$\mathrm{Mg}^{2+}$ & $\mathbf{0 . 9 9}$ & 0.23 & 0.53 & & & & \\
& 0.00 & 0.01 & 0.00 & & & & \\
$\mathrm{Ca}^{2+}$ & 0.41 & 0.55 & $\mathbf{0 . 6 7}$ & 0.48 & & & \\
& 0.00 & 0.00 & 0.00 & 0.00 & & & \\
$\mathrm{NO}_{3}^{-}$ & 0.39 & $\mathbf{0 . 8 6}$ & 0.59 & 0.44 & $\mathbf{0 . 7 8}$ & & \\
& 0.00 & 0.00 & 0.00 & 0.00 & 0.00 & & \\
$\mathrm{Cl}^{-}$ & $\mathbf{1 . 0 0}$ & 0.19 & 0.49 & $\mathbf{0 . 9 9}$ & 0.39 & 0.38 & \\
& 0.00 & 0.04 & 0.00 & 0.00 & 0.00 & 0.00 & \\
$\mathrm{SO}_{4}^{2-}$ & 0.29 & $\mathbf{0 . 8 2}$ & $\mathbf{0 . 6 1}$ & 0.32 & $\mathbf{0 . 6 6}$ & $\mathbf{0 . 8 1}$ & 0.29 \\
& 0.00 & 0.00 & 0.00 & 0.00 & 0.00 & 0.00 & 0.00 \\
\hline
\end{tabular}

other months they were lower than 1.0. The monthly VWMC of major ions in rainwater samples are depicted in Fig. 5. The mean concentration of major ions in samples during summer (July-September), typhoons, and winter (NovemberDecember) are illustrated in Fig. 6. More than half of the total rainfall occurs in summer, while in the winter, precipitation is less than $10 \%$ of the total in Korea (Lee et al., 2000). Thus, seasonal variations of ionic concentration in rainwater were mainly affected by precipitation patterns and monsoonal winds (Lee et al., 2000). The major ions had relatively higher concentrations in the winter, which is a pattern opposite to the trend in rainfall. The ionic concentrations showed decreasing trends with increasing rainfall amounts, suggesting a dilution effect of rainwater on precipitation chemistry. The lowest ion concentrations were observed during typhoon periods, except for $\mathrm{Na}^{+}$and $\mathrm{Cl}^{-}$which are typical marine components.

\subsection{Correlation analysis}

To investigate and identify potential correlation between major ions in rainwater samples, the Pearson correlation analysis was applied (Table 3). A strong correlation was found between $\mathrm{Na}^{+}$and $\mathrm{Mg}^{2+}\left(R^{2}=0.99\right)$ and between $\mathrm{Na}^{+}$and $\mathrm{Cl}^{-}\left(R^{2}=1.00\right)$, suggesting a marine source. The high cor- 


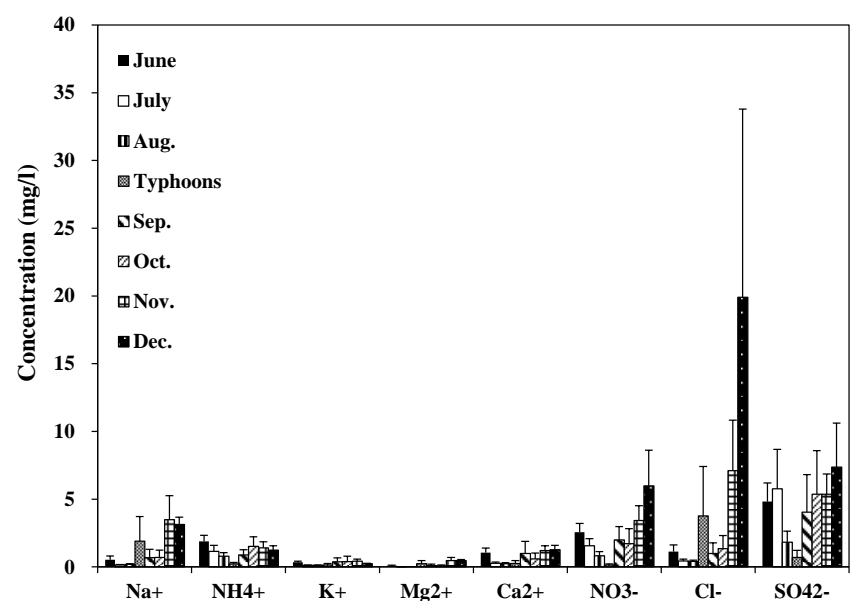

Figure 5. Monthly variation of VWMC of major ions in rainwater samples during 2012.

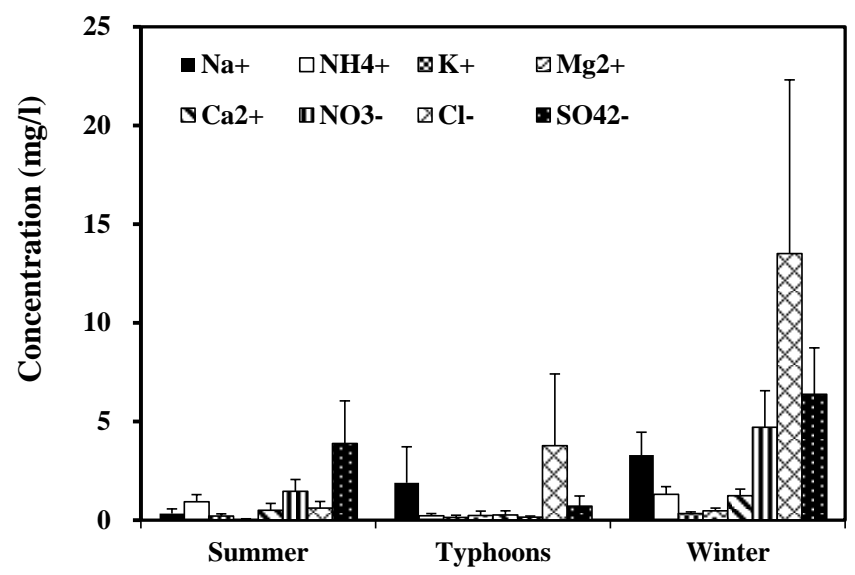

Figure 6. Mean concentration of major ions in rainwater samples during summer (July-September), typhoons, and winter (November-December).

relation between $\mathrm{Mg}^{2+}$ and $\mathrm{Cl}^{-}\left(R^{2}=0.99\right)$ also corresponds to salts of marine origin. Relatively high correlations between $\mathrm{NO}_{3}^{-}$and $\mathrm{NH}_{4}^{+}\left(R^{2}=0.86\right)$, and between $\mathrm{SO}_{4}^{2-}$ and $\mathrm{NH}_{4}^{+}\left(R^{2}=0.82\right)$, may reveal co-occurrence of $\mathrm{NH}_{4}^{+}$ with $\mathrm{SO}_{4}^{2-}$ and $\mathrm{NO}_{3}^{-}$in rainwater. This was probably due to dissolution of secondary inorganic aerosols $\left(\left(\mathrm{NH}_{4}\right)_{2} \mathrm{SO}_{4}\right.$ and $\mathrm{NH}_{4} \mathrm{NO}_{3}$ ) in rainwater (Panyakapo and Onchang, 2008). Among the compounds of ammonium, ammonium sulfate is known to predominate in the atmosphere (Seinfeld, 1986). However, our study showed slightly higher correlation between $\mathrm{NH}_{4}^{+}$and $\mathrm{NO}_{3}^{-}\left(R^{2}=0.86\right)$ than between $\mathrm{NH}_{4}^{+}$and $\mathrm{SO}_{4}^{2-}\left(R^{2}=0.82\right)$, indicating that $\mathrm{NH}_{4} \mathrm{NO}_{3}$ dominates over $\left(\mathrm{NH}_{4}\right)_{2} \mathrm{SO}_{4}$. The dominance of $\mathrm{NH}_{4} \mathrm{NO}_{3}$ has also been reported previously (Saxena et al., 1996). The high correlation between $\mathrm{SO}_{4}^{2-}$ and $\mathrm{NO}_{3}^{-}$suggests a common source origin, due to the co-emission of precursors $\left(\mathrm{SO}_{2}\right.$ and $\left.\mathrm{NO}_{x}\right)$ from the same sources, such as fossil fuel burning, and the similar-
Table 4. Concentrations of trace metals in rainwater samples (ppb)

\begin{tabular}{lrrrr}
\hline $\begin{array}{l}\text { Trace } \\
\text { metals }\end{array}$ & VWMC & SDVWMC & Min & Max \\
\hline $\mathrm{Zn}$ & 18.78 & 14.08 & N.D. & 567.20 \\
$\mathrm{Al}$ & 12.99 & 6.64 & N.D. & 104.60 \\
$\mathrm{Fe}$ & 11.00 & 6.55 & N.D. & 74.51 \\
$\mathrm{Mn}$ & 4.58 & 2.89 & N.D. & 33.45 \\
$\mathrm{~Pb}$ & 3.10 & 1.77 & N.D. & 25.01 \\
$\mathrm{Cu}$ & 1.69 & 0.89 & N.D. & 14.70 \\
$\mathrm{Ni}$ & 0.28 & 0.18 & N.D. & 8.04 \\
$\mathrm{Cd}$ & 0.09 & 0.05 & N.D. & 1.14 \\
$\mathrm{Cr}$ & 0.06 & 0.03 & N.D. & 0.47 \\
\hline
\end{tabular}

WHO drinking water guidelines: $\mathrm{Zn}: 3 \mathrm{mg} \mathrm{L}^{-1}$, Al: $0 . \mathrm{mg} \mathrm{L}^{-1}$, Fe: $0.3 \mathrm{mg} \mathrm{L}^{-1}, \mathrm{Mn}: 0.5 \mathrm{mg} \mathrm{L}^{-1}, \mathrm{~Pb}: 0.01 \mathrm{mg} \mathrm{L}^{-1}, \mathrm{Cu}: 2 \mathrm{mg} \mathrm{L}^{-1}, \mathrm{Ni}$ $0.07 \mathrm{mg} \mathrm{L}^{-1}$, Cd: $0.03 \mathrm{mg} \mathrm{L}^{-1}$, Cr: $0.05 \mathrm{mg} \mathrm{L}^{-1}$.

ity of their behavior in precipitation. Correlations were also found between $\mathrm{NO}_{3}^{-}$and $\mathrm{Ca}^{2+}\left(R^{2}=0.78\right)$, and between $\mathrm{SO}_{4}^{2-}$ and $\mathrm{Ca}^{2+}\left(R^{2}=0.66\right)$, suggesting that $\mathrm{Ca}\left(\mathrm{NO}_{3}\right)_{2}$ and $\mathrm{CaSO}_{4}$ are formed from the neutralization reactions of acidity in rainwater (Zhao et al., 2013). Moderate correlation was found between $\mathrm{K}^{+}$and $\mathrm{Ca}^{2+}$, indicating a common origin in marine aerosol. $\mathrm{K}^{+}$and $\mathrm{SO}_{4}^{2-}$ were somewhat correlated $\left(R^{2}=0.61\right)$, suggesting the occurrence of reactions between the acid $\mathrm{H}_{2} \mathrm{SO}_{4}$ and the alkaline compounds carried into the atmosphere by windblown sea salts/dusts (Huang et al., 2008).

\subsection{Trace metals}

The VWMCs of trace metals in rainwater samples are presented in Table 4. The concentration of trace metals decreased in the order $\mathrm{Zn}>\mathrm{Al}>\mathrm{Fe}>\mathrm{Mn}>\mathrm{Pb}>\mathrm{Cu}>\mathrm{Ni}>\mathrm{Cd}>\mathrm{Cr}$. Table 5 provides the comparison of trace metal concentrations in precipitation from this study with values obtained from other rural and urban regions of the world. This order of element abundance is similar to those obtained from precipitation in Chuncheon, Suwon, Mexico, and New Castle in the USA. While $\mathrm{Al}$ and $\mathrm{Fe}$ were much higher in Ankara, the authors indicate that this is due to its location in the middle of the semi-arid Anatolia Plateau. In general, the concentrations of trace metals in Gwangju are lower than those in other countries, due to the lack of industry in the city. With respect to $\mathrm{Al}, \mathrm{Fe}, \mathrm{Ni}, \mathrm{Cd}$, and $\mathrm{Cr}$, concentrations in this study were the lowest of all the other countries. Most of the industries in Korea are located in and near Seoul and the Gyeonggi Province, but Gwangju is a city of education, culture, universities and limited industrial activity. With respect to trace metals, values measured in Ankara, Turkey, were the highest of all of the other countries with the exception of $\mathrm{Zn}$. 
Table 5. Comparison between the VWMC of trace metals in precipitation in Gwangju and at other locations.

\begin{tabular}{lrrrrrrrrrl}
\hline Location & $\mathrm{Zn}$ & $\mathrm{Al}$ & $\mathrm{Fe}$ & $\mathrm{Mn}$ & $\mathrm{Pb}$ & $\mathrm{Cu}$ & $\mathrm{Ni}$ & $\mathrm{Cd}$ & $\mathrm{Cr}$ & References \\
\hline This study & 18.78 & 12.99 & 11.00 & 4.58 & 3.10 & 1.69 & 0.28 & 0.09 & 0.06 & \\
Chuncheon, Korea & 9.9 & 13.85 & & 3.23 & 1.51 & 1.73 & 0.52 & 0.07 & & Kim et al. (2012) \\
Suwon, Korea & 13.06 & & & & 9.98 & 6.08 & 0.66 & 0.2 & 0.43 & Jung et al. (2007) \\
Mexico & & 50.7 & & 9.64 & 2.48 & & 3.37 & 0.41 & 0.52 & Baez et al. (2007) \\
Ankara, Turkey & 0.03 & 980 & 750 & & 19.1 & 6.1 & 4.1 & 9.5 & 3 & Kaya and Tuncel (1997) \\
Singapore & 7.23 & 18.44 & 23.91 & 2.78 & 3.37 & 5.58 & 3.86 & 0.33 & 1.62 & Hu and Balasubarmanian (2003) \\
Jordan & 6.52 & 382 & 92 & 2.11 & 2.57 & 3.08 & 2.62 & 0.42 & 0.77 & Al-Momani et al. (2003) \\
New Castle, NH, USA & 25.5 & 24.4 & 22.8 & & 1.31 & 1.33 & 0.85 & 0.24 & 0.14 & Pike and Moran (2001) \\
\hline
\end{tabular}

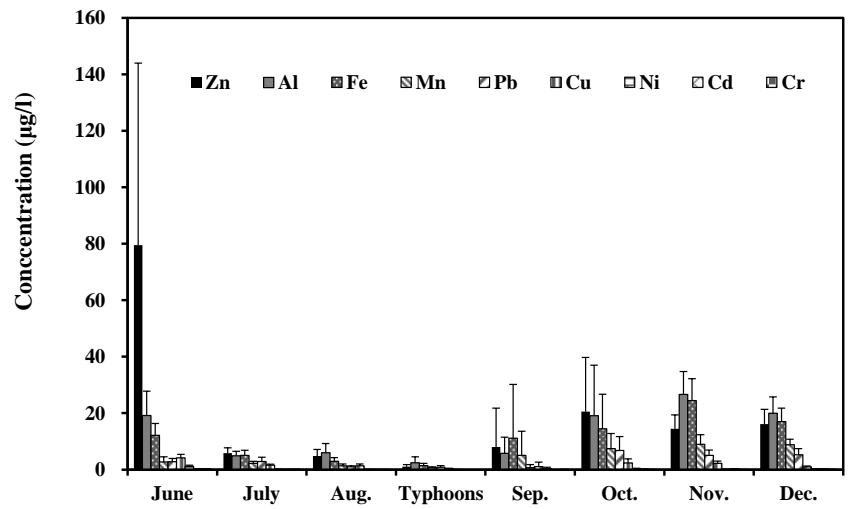

Figure 7. Monthly variation of VWMC of trace metals in rainwater samples during 2012.

\subsection{Variations in trace metal levels in rainwater}

Monthly variations of the VWMC of trace metals in rainwater are shown in Fig. 7. As expected, the lowest concentrations of trace metals were found during typhoon periods (July-September), caused by more frequent rain events and the consequent dilution effect. The samples collected in winter had higher concentrations of trace metals than the samples in summer (Fig. 8). Similar seasonal variations have been reported in other studies (Cheng et al., 2011; Kim et al., 2012).

\subsection{Correlation analysis}

Table 6 lists the matrix correlation between ions and trace metals (correlation coefficients greater than 0.5 are marked in bold letters). Moderate correlation was found among the trace metals and $\mathrm{NH}_{4}^{+}, \mathrm{NO}_{3}^{-}$, and $\mathrm{SO}_{4}^{2-}$, with the exception of $\mathrm{Cr}$ and $\mathrm{Zn}$, suggesting the anthropogenic origin of the species. These correlations were also observed in previous studies (Garcia et al., 2006; Jung et al., 2011). Significant correlations between $\mathrm{SO}_{4}^{2-}$ and trace metals in rainwater were observed in Clarke and Radojevic (1987).

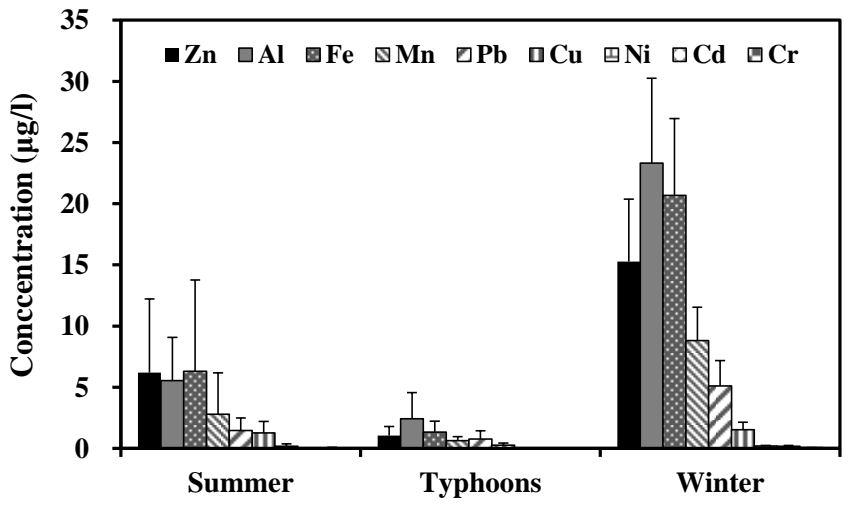

Figure 8. Mean concentration of trace metals in rainwater samples during summer (July-September), typhoons, and winter (November-December).

\subsection{Enrichment factor analysis}

An enrichment factor (EF) has been used to evaluate the contribution of non-crustal sources (Kaya and Tuncel, 1997; Kim et al., 2012). The EF values were calculated using the following relation:

$\mathrm{EF}=\left(C_{X} / C_{\mathrm{Al}}\right.$ sample $) /\left(C_{X} / C_{\mathrm{Al}}\right.$ crust $)$,

where $\left(C_{X} / C_{\mathrm{Al}}\right.$ sample) is the ratio of the concentration of an element $X$ and $\mathrm{Al}$ in the rainwater sample and $\left(C_{X} / C_{\mathrm{Al}}\right.$ crust) is the same ratio in crustal material, adapted from Wedepohl (1995).

EFs from 1 to 10 suggest crustal origin; EFs from 10 to 100 suggest moderate anthropogenic enrichment; and EFs $>100$ indicate anthropogenic origin. Fig. 9 presents the bars of the $\mathrm{EF}$ of the trace elements. $\mathrm{Fe}$ and $\mathrm{Cr}$ with $\mathrm{EF}$ values of 1 10 were significantly enriched by soil. Mn and $\mathrm{Ni}$ with EF values in the range of 10-100 were moderately enriched by anthropogenic sources, while $\mathrm{Zn}, \mathrm{Pb}, \mathrm{Cu}$, and $\mathrm{Cd}$ with $\mathrm{EF}$ values exceeding 100 were highly enriched by human activities. Ni and $\mathrm{Mn}$ are mainly emitted from manufacture of ferroalloys and from oil-fired furnaces (Báez et al., 2007). The primary sources of $\mathrm{Zn}, \mathrm{Pb}, \mathrm{Cu}$, and $\mathrm{Cd}$ are industrial and traffic activities such as metal smelting and fuel combustion (AlMomani, 2003; Cheng et al., 2011). The variation of monthly 
Table 6. Correlation coefficients and $P$ value between ions and trace metals in rainwater 1 samples from Gwangju $(n=113)$.

\begin{tabular}{ccccccccc}
\hline & $\mathrm{Na}^{+}$ & $\mathrm{NH}_{4}^{+}$ & $\mathrm{K}^{+}$ & $\mathrm{Mg}^{2+}$ & $\mathrm{Ca}^{2+}$ & $\mathrm{NO}_{3}^{-}$ & $\mathrm{Cl}^{-}$ & $\mathrm{SO}_{4}^{2-}$ \\
\hline $\mathrm{Al}$ & 0.32 & $\mathbf{0 . 6 0}$ & 0.44 & 0.36 & $\mathbf{0 . 5 1}$ & $\mathbf{0 . 6 6}$ & 0.33 & $\mathbf{0 . 5 9}$ \\
& 0.00 & 0.00 & 0.00 & 0.00 & 0.00 & 0.00 & 0.00 & 0.00 \\
$\mathrm{Cr}$ & 0.17 & 0.41 & 0.19 & 0.20 & 0.30 & 0.41 & 0.18 & 0.42 \\
& 0.07 & 0.00 & 0.04 & 0.03 & 0.00 & 0.00 & 0.06 & 0.00 \\
$\mathrm{Mn}$ & 0.36 & 0.35 & 0.29 & 0.40 & $\mathbf{0 . 5 2}$ & $\mathbf{0 . 5 7}$ & 0.36 & 0.38 \\
& 0.00 & 0.00 & 0.00 & 0.00 & 0.00 & 0.00 & 0.00 & 0.00 \\
$\mathrm{Fe}$ & 0.36 & $\mathbf{0 . 5 3}$ & 0.39 & 0.41 & 0.49 & $\mathbf{0 . 6 4}$ & 0.37 & $\mathbf{0 . 5 3}$ \\
& 0.00 & 0.00 & 0.00 & 0.00 & 0.00 & 0.00 & 0.00 & 0.00 \\
$\mathrm{Ni}$ & 0.02 & $\mathbf{0 . 5 3}$ & 0.32 & 0.05 & 0.23 & 0.39 & 0.03 & 0.37 \\
& 0.82 & 0.00 & 0.00 & 0.63 & 0.01 & 0.00 & 0.79 & 0.00 \\
$\mathrm{Cu}$ & 0.05 & $\mathbf{0 . 6 7}$ & 0.35 & 0.07 & 0.35 & $\mathbf{0 . 5 8}$ & 0.06 & $\mathbf{0 . 5 8}$ \\
& 0.59 & 0.00 & 0.00 & 0.43 & 0.00 & 0.00 & 0.54 & 0.00 \\
$\mathrm{Zn}$ & 0.08 & 0.24 & 0.32 & 0.12 & 0.33 & 0.22 & 0.08 & 0.20 \\
& 0.39 & 0.01 & 0.00 & 0.19 & 0.00 & 0.02 & 0.38 & 0.03 \\
$\mathrm{Cd}$ & 0.31 & $\mathbf{0 . 5 9}$ & 0.42 & 0.36 & $\mathbf{0 . 5 0}$ & $\mathbf{0 . 6 1}$ & 0.33 & $\mathbf{0 . 6 4}$ \\
& 0.00 & 0.00 & 0.00 & 0.00 & 0.00 & 0.00 & 0.00 & 0.00 \\
$\mathrm{~Pb}$ & $\mathbf{0 . 5 0}$ & $\mathbf{0 . 5 6}$ & 0.44 & $\mathbf{0 . 5 4}$ & 0.39 & $\mathbf{0 . 6 3}$ & $\mathbf{0 . 5 1}$ & $\mathbf{0 . 6 3}$ \\
& 0.00 & 0.00 & 0.00 & 0.00 & 0.00 & 0.00 & 0.00 & 0.00 \\
\hline
\end{tabular}

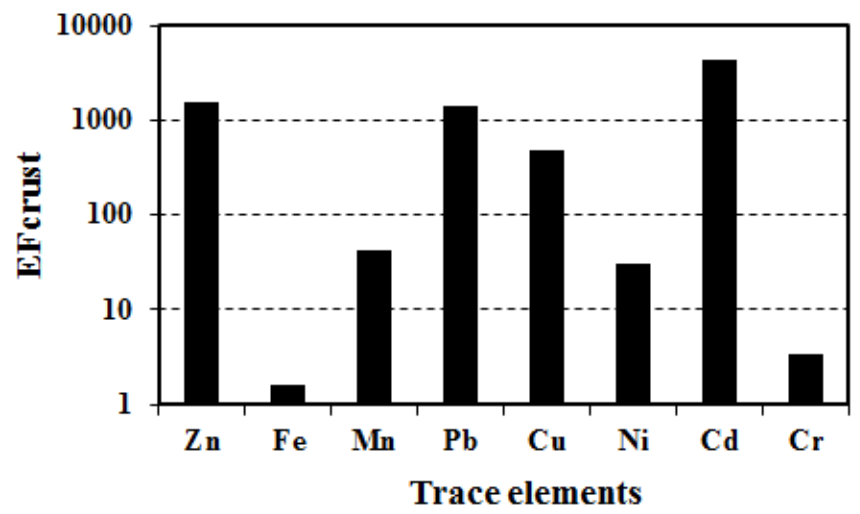

Figure 9. Average EFs of trace metals in rainwater in the Gwangju area during 2012.

EFs of trace metals in rainwater is depicted in Fig. 10. The monthly EFs of trace metals were relatively high during summer (from June to September). Cd and Cr were not detected during the typhoon periods or in September. The highest EF values of $\mathrm{Fe}$ and $\mathrm{Mn}, \mathrm{Pb}, \mathrm{Cu}, \mathrm{Cd}$, and $\mathrm{Cr}$, and $\mathrm{Zn}$ and $\mathrm{Ni}$ were found during September, July, and June, respectively.

\subsection{Comparison of chemical components in initial and subsequent rainfall}

A comparison of the mean concentrations of major ions and trace metals in initial $(n=40)$ and subsequent $(n=73)$ rainfall samples is presented in Fig. 11. Greater amounts of major ions and trace metals appeared in initial rainfall samples than in subsequent samples as large amount of pollutants were dissolved in less water. Mean values of TOC, TN, UV,
Table 7. Mean values of TOC, TN, UV, SUVA, and $\mathrm{pH}$ and conductivity in initial $(n=40)$ and subsequent $(n=73)$ rainfall during 2012.

\begin{tabular}{lrr|rr}
\hline & \multicolumn{2}{c|}{ Initial rainfall } & \multicolumn{2}{c}{$\begin{array}{c}\text { Subsequent } \\
\text { rainfall }\end{array}$} \\
\cline { 2 - 5 } & Mean & SD & Mean & SD \\
\hline TOC $\left(\mathrm{mg} \mathrm{C} \mathrm{L}^{-1}\right)$ & 2.18 & 1.41 & 1.11 & 0.68 \\
TN $\left(\mathrm{mg} \mathrm{N} \mathrm{L}^{-1}\right)$ & 1.95 & 1.19 & 0.79 & 0.47 \\
$\mathrm{UV}\left(\mathrm{cm}^{-1}\right)$ & 0.0244 & 0.0135 & 0.0111 & 0.0073 \\
$\mathrm{SUVA}$ & 1.19 & 0.39 & 1.06 & 0.33 \\
$\mathrm{pH}$ & 5.97 & 0.52 & 5.55 & 0.64 \\
Conductivity $\left(\mu \mathrm{S} \mathrm{cm}^{-1}\right)$ & 38.17 & 25.67 & 25.72 & 19.07 \\
\hline
\end{tabular}

SD: standard deviation.

SUVA, $\mathrm{pH}$, and conductivity in initial $(n=40)$ and subsequent $(n=73)$ samples are shown in Table 7. Again, higher mean concentrations of TOC, TN, UV, SUVA, $\mathrm{pH}$, and conductivity were observed in initial rainfall, with the values of TOC, TN, and UV in initial rainfall being twice as high as in subsequent rainfall.

\subsection{Factor analysis}

Factor analysis (principal component analysis) has been widely applied in previous studies to investigate the influence of different sources on the chemical components in precipitation (Báez et al., 2006; Garcia et al., 2006; Panyakapo and Onchang, 2008). A varimax-rotated principal component analysis (PCA) was performed using Minitab version 16 for Windows. Table 8 presents the result of the factor analy- 


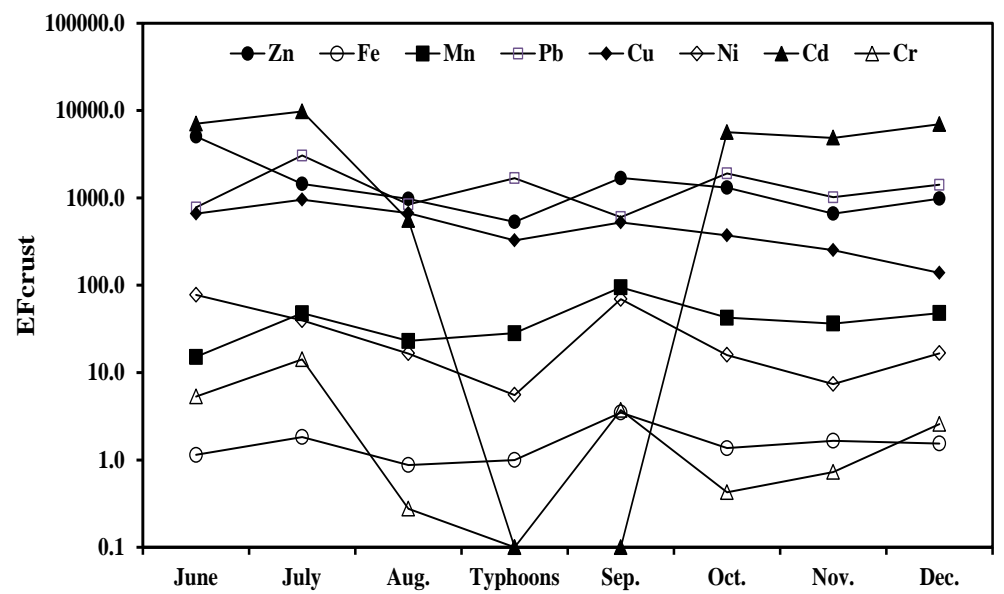

Figure 10. Monthly variation of EFs of trace metals in rainwater in the Gwangju area during 2012.
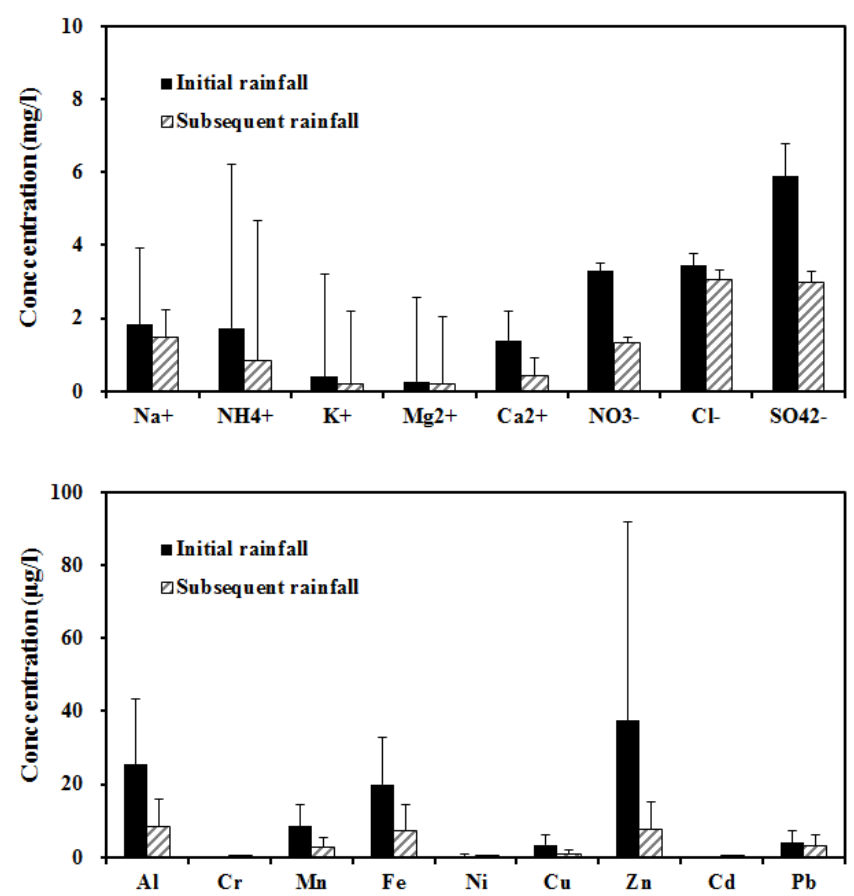

Figure 11. Comparison of mean concentration of major ions and trace metals in initial $(n=40)$ and subsequent $(n=73)$ rainfall during 2012 .

sis that identified three factors that explained approximately $73.1 \%$ of the total variance. Factor 1 explained $27.1 \%$ of the total variance with high loadings for $\mathrm{SO}_{4}^{2-}, \mathrm{NO}_{3}^{-}$, and $\mathrm{NH}_{4}^{+}$, and moderate loadings for $\mathrm{K}^{+}, \mathrm{Ca}^{2+}$, and $\mathrm{Cu}$. This factor indicates marine sources for $\mathrm{K}^{+}$and $\mathrm{Ca}^{2+}$, with an anthropogenic source for $\mathrm{Cu}$, as is indicated by $\mathrm{EF}$. $\mathrm{Cu}$ is a typical metal contaminant emitted from industrial processes (Wong et al., 2003). The loadings of $\mathrm{SO}_{4}^{2-}, \mathrm{NO}_{3}^{-}$, and $\mathrm{NH}_{4}^{+}$ suggest that these ions come from anthropogenic sources associated with precursor gases such as $\mathrm{SO}_{2}$ and $\mathrm{NO}_{x}$. The
Table 8. Factor analysis of chemical constituents in rainwater. Bold numbers are significant at $>0.5$.

\begin{tabular}{lrrr}
\hline Variable & Factor 1 & Factor 2 & Factor 3 \\
\hline $\mathrm{Na}^{+}$ & 0.12 & $\mathbf{0 . 9 7}$ & 0.10 \\
$\mathrm{NH}_{4}^{+}$ & $\mathbf{0 . 8 8}$ & 0.03 & 0.27 \\
$\mathrm{~K}^{+}$ & $\mathbf{0 . 6 1}$ & 0.46 & 0.11 \\
$\mathrm{Mg}^{2+}$ & 0.15 & $\mathbf{0 . 9 6}$ & 0.15 \\
$\mathrm{Ca}^{2+}$ & $\mathbf{0 . 6 7}$ & 0.39 & 0.19 \\
$\mathrm{NO}_{3}^{-}$ & $\mathbf{0 . 8 5}$ & 0.29 & 0.28 \\
$\mathrm{Cl}^{-}$ & 0.11 & $\mathbf{0 . 9 6}$ & 0.12 \\
$\mathrm{SO}_{4}^{2-}$ & $\mathbf{0 . 8 5}$ & 0.18 & 0.23 \\
$\mathrm{Al}$ & 0.51 & 0.20 & $\mathbf{0 . 7 1}$ \\
$\mathrm{Cr}$ & 0.14 & 0.08 & $\mathbf{0 . 7 9}$ \\
$\mathrm{Fe}$ & 0.41 & 0.28 & $\mathbf{0 . 7 6}$ \\
$\mathrm{Ni}$ & 0.44 & -0.18 & $\mathbf{0 . 5 0}$ \\
$\mathrm{Zn}$ & 0.04 & 0.02 & $\mathbf{0 . 6 2}$ \\
$\mathrm{Cd}$ & 0.47 & 0.24 & $\mathbf{0 . 6 3}$ \\
$\mathrm{Pb}$ & 0.44 & 0.42 & $\mathbf{0 . 5 9}$ \\
$\mathrm{Mn}$ & 0.36 & 0.35 & $\mathbf{0 . 5 0}$ \\
$\mathrm{Cu}$ & $\mathbf{0 . 7 5}$ & -0.14 & 0.41 \\
\% total & 28.5 & 22.4 & 22.2 \\
variance & & & \\
\hline
\end{tabular}

co-occurrence of $\mathrm{NH}_{4}^{+}$with $\mathrm{NO}_{3}^{-}$and $\mathrm{SO}_{4}^{2-}$ are caused by dissolution of aerosols and secondary pollutants containing $\left(\mathrm{NH}_{4}\right)_{2} \mathrm{SO}_{4}$ and $\mathrm{NH}_{4} \mathrm{NO}_{3}$ in rainwater. Factor 2 accounted for $22.4 \%$ of the total variance with high loading for $\mathrm{Na}^{+}$, $\mathrm{Mg}^{2+}$, and $\mathrm{Cl}^{-}$, indicating the influence of sea spray. Factor 3 , which explained $22.2 \%$ of the total variance, proposed moderate loadings of most of the trace metals. This factor indicates the contribution of anthropogenic sources and significant crustal contributions for $\mathrm{Al}, \mathrm{Cr}$, and $\mathrm{Fe}$, as indicated by EF. Overall, the anthropogenic pollutants, sea salts, and crustal materials were the main sources of the chemical species in rainwater in Gwangju. 

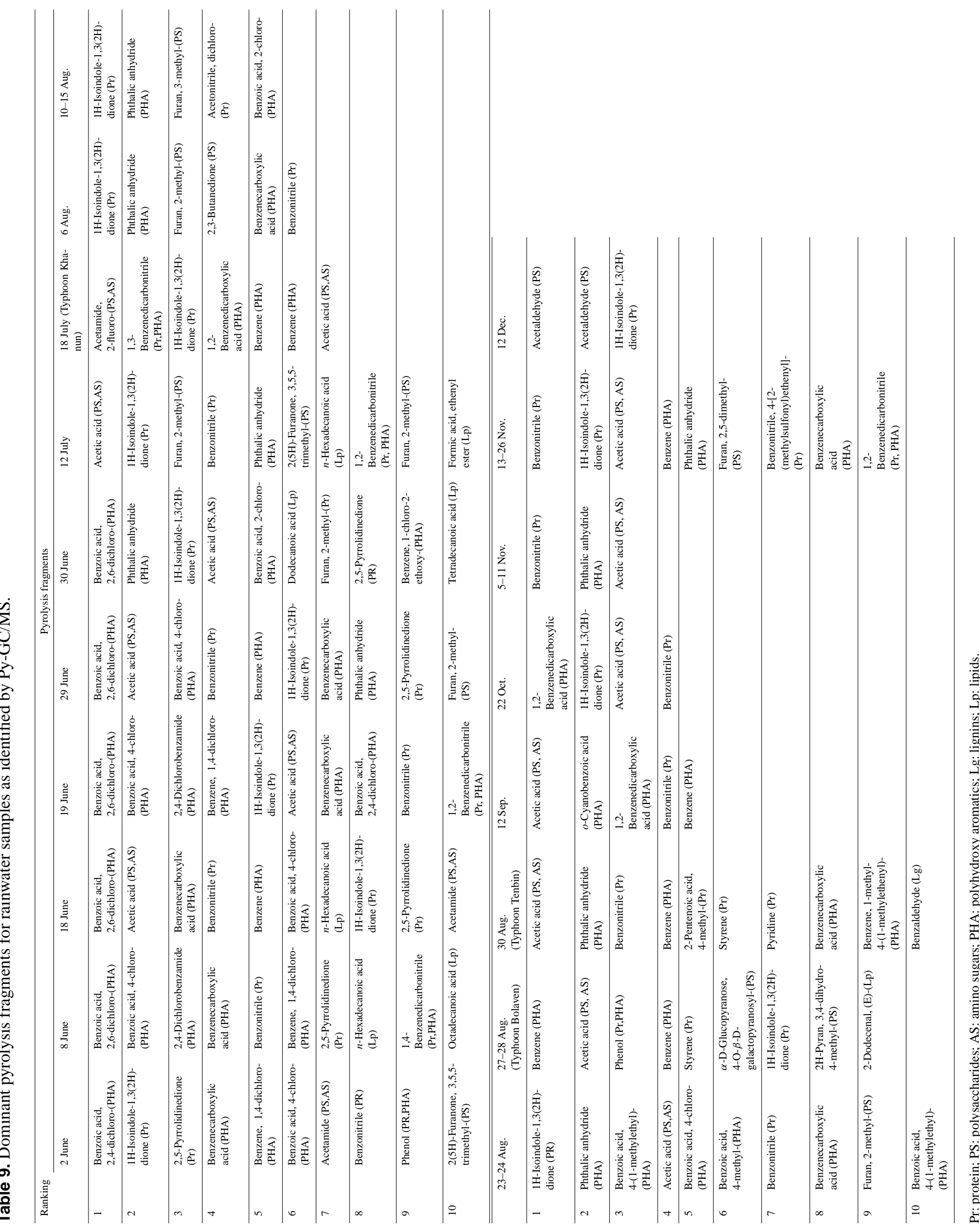


\subsection{Organic compounds in rainwater}

Table 9 lists dominant pyrolysis fragments for rainwater organic compounds collected from June to December 2012 as identified by Py-GC/MS based on peak area percent of pyrochromatograms. Each sample could be fractionated and categorized into polysaccharides (PS), amino sugars (AS), proteins (PR), polyhydroxy aromatics (PHA), lignins (LG), and lipids (Lp) (Leenher and Croue, 2003). Benzoic acids were the most abundant compound during June, which originates from anthropogenic sources such as fossil fuel combustion. Kawamura et al. (1986) identified benzoic acids in used engine oil and motor exhaust. Benzoic acids have been found in rainfall in Los Angeles and Norway (Lunde et al., 1977; Kawamura and Kaplan, 1983). 2-Fluoro-acetamide and acetic acids were the most abundant compounds in July and September. Acetamide was one of the major pyrolysis organic compounds with precipitation in Königstein, Germany (Laniewski et al., 1998), which is a source of plasticizer and industrial solvents and normally found near industrial areas (Cho and Shin, 2013). Acetic acids originate from primary natural sources such as emissions from microbial activity and vegetation and from anthropogenic sources (biomass burning and traffic exhaust) (Avery et al., 1991). It has been found in rainwaters from both developed and remote areas (Galloway et al., 1982; Keene and Galloway, 1984). 1H-Isoindole-1,3(2H)-dione, phthalic anhydride, benzene, and acetic acids were the most abundant species during August. 1H-Isoindole-1,3(2H)-dione was one of the major pyrolysis organic compounds from precipitation in Königstein, Germany (Laniewski et al., 1998), and was found to be from tire-derived aggregates. Phthalic anhydride originates from agricultural crop burning and open burning of scrap tires (Lemieux et al., 2004). Benzene is an important aromatic compound from gasoline, automobile exhaust, and the urban atmosphere (Sigsby et al., 1987). Benzene was generally found as the major compound of volatile organic carbons in rainwater from Yokohama, Japan (Sato et al., 2006). 1,2-Benzenedicarboxylic acids were the most abundant compound in October and have been identified to come from particulate automobile exhaust emissions, cigarette combustion, degradation of plastics, and products of lignin-type material metabolized by microorganisms (Johnstone and Plimmer, 1959; Simoneit, 1985; Kawamura and Kaplan, 1987). Benzonitrile was the most abundant species during November, which has been found in accidental vehicle fires (Estrellan and Lino, 2010) and biomass combustion in improved stoves in rural China (Wang et al., 2009). Acetaldehyde was the most abundant compound in December, probably derived from primary incomplete combustion of fossil fuels and secondary photochemical reactions of hydrocarbons emitted from anthropogenic sources (Sakugawa et al., 1993). Acetaldehyde was also detected in Los Angeles (Kawamura et al., 2001) and Spain (Peña et al., 2002). Among fatty acids, $n$-hexadecanoic acid $\left(C_{16}\right)$, octadecanoic acid $\left(C_{18}\right)$, and tetradecanoic acid $\left(C_{14}\right)$ were found in the top 10 organic compounds during June and July. This is in agreement with previous work (Kawamura and Kaplan, 1986), where lower molecular fatty acids $\left(C_{12}-C_{19}\right)$ are major compounds while higher molecular weight fatty acids $\left(C_{20}-C_{30}\right)$ are minor. A major source of fatty acids $(C<20)$ is known to come from cooking and biomass combustion in urban areas (Rogge et al., 1991; Xu et al., 2008). All results in the present study indicate that anthropogenic sources were significant contributors to the organic compounds present in rainwater.

\section{Conclusions}

Rainwater samples collected from Gwangju, Korea, during June-December 2012 were analyzed to determine the chemical composition and organic compounds present in rainwater. Even though our study period was quite short compared to other studies, we tried to present a valuable data analysis of the chemical composition and organic compounds in rainwater between summer and winter, as there are two distinct seasons with rain in Korea. The VWM of $\mathrm{pH}$ was 5.78 (ranging from 3.83 to $8.90)$ and acid rain $(\mathrm{pH}<5.6)$ frequency was $50 \%$. The VWMC of major ions and trace metals followed the order $\mathrm{Cl}^{-}>\mathrm{SO}_{4}^{2-}>\mathrm{NH}_{4}^{+}>\mathrm{Na}^{+}>\mathrm{NO}_{3}^{-}>\mathrm{Ca}^{2+}>\mathrm{Mg}^{2+}>\mathrm{K}^{+}$ and $\mathrm{Zn}>\mathrm{Al}>\mathrm{Fe}>\mathrm{Mn}>\mathrm{Pb}>\mathrm{Cu}>\mathrm{Ni}>\mathrm{Cd}>\mathrm{Cr}$. The higher VWM values of TOC, TN, UV, SUVA, pH, conductivity, major ions, and trace metals appeared in the initial rainfall events rather than in subsequent rainfall events. The VWMCs of major ions and trace metals were relatively lower in summer due to the dilution effect. The lowest VWMCs of ions (except for $\mathrm{Na}^{+}$and $\mathrm{Cl}^{-}$) and trace metals were observed during typhoons. Based on EF values, $\mathrm{Zn}, \mathrm{Pb}$, $\mathrm{Cu}, \mathrm{Ni}, \mathrm{Cd}$, and $\mathrm{Mn}$ were emitted mainly from anthropogenic sources whereas $\mathrm{Fe}$ and $\mathrm{Cr}$ originated from crustal sources. The factor analysis (principal component analysis) revealed that the anthropogenic pollutants, sea salts, and crustal materials were the main sources of ionic species and trace metals in rainwaters. The most abundant pyrolysis fragments for rainwater organic compounds were benzoic acids, 1H-isoindole-1,3(2H)-dione, phthalic anhydride, benzene, acetic acids, 1,2-benzenedicarboxylic acids, benzonitrile, acetaldehyde, and acetamide, indicating that anthropogenic pollutants are significant contributors to rainwater organic compounds.

Acknowledgements. This research was supported by the National Research Foundation of Korea (NRF) grant funded by the Korean government (MSIP) (no. 2011-0030040 (ERC) and no. NRF-2015R1A5A7037825).

Edited by: A. Mittal 


\section{References}

Al-Momani, I. F.: Trace elements in atmospheric precipitation at Northern Jordan measured by ICP-MS: acidity and possible sources, Atmos. Environ., 37, 4507-4515, 2003.

Avery Jr., G. B., Willey, J. D., and Wilson, C. A.: Formic and acetic acids in coastal North Carolina rainwater, Environ. Sci. Technol., 25, 1875-1880, 1991.

Báez, A. P., Belmont, R. D., García, R. M., Torres, M. C. B., and Padilla, H. G.: Rainwater chemical composition at two sites in Central Mexico, Atmos. Res., 80, 67-85, 2006.

Báez, A. P., Belmont, R. D., García, R. M., Padilla, H. G., and Torres, M. C. B.: Chemical composition of rainwater collected at a southwest site of Mexico City, Mexico, Atmos. Res., 86, 61-75, 2007.

Bard, S. M.: Global transport of anthropogenic contaminants and the consequences for the arctic marine ecosystem, Mar. Pollut. Bull., 38, 356-379, 1999.

Barrie, L. A., Lindberg, S. E., Chan, W. H., Ross, H. B., Arimoto, R., and Church, T. M.: On the concentration of trace metals in precipitation, Atmos. Environ., 21, 1133-1135, 1987.

Başak, B. and Alagha, O.: The chemical composition of rainwater over Büyükçekmece Lake, Istanbul, Atmos. Res, 71, 275-288, 2004.

Bruchet, A., Rousseau, C., and Mallevialle, J.: Pyrolysis-GC/MS for investigating high-molecular weight THM precursors and other refractory organics, J. Am. Water Works Ass., 82, 66-74, 1990.

Cerón, R., Cerón, J., Carballo, C., Aguilar, C., Montalvo, C., Benítez, J., Villareal, Y., and Gómez, M.: Chemical composition, fluxes and seasonal variation of acid deposition in Carmen Island, Campeche, Mexico, J. Environ. Prot., 4, 50-56, 2013.

Charlson, R. J. and Rodhe, H.: Factors controlling the acidity of natural rainwater, Nature, 295, 683-685, 1982.

Cheng, M. C., You, C. F., Lin, F. J., Huang, K. F., and Chung, C. H.: Sources of $\mathrm{Cu}, \mathrm{Zn}, \mathrm{Cd}$ and $\mathrm{Pb}$ in rainwater at a subtropical islet offshore northern Taiwan, Atmos. Environ., 45, 1919-1928, 2011.

Cho, Y. H. and Shin, H. S.: Determination of trace levels of acetamide, propanamide, and butyramide in surface and drinking water using gas chromatography-mass spectrometry after derivatization with 9-xanthydrol, Anal. Chim. Acta, 787, 111-117, 2013.

Clarke, A. G. and Radojevic, M.: Oxidation of $\mathrm{SO}_{2}$ in rainwater and its role in acid rain chemistry, Atmos. Environ., 21, 1115-1123, 1987.

Dianwu, Z. and Anpu, W.: Estimation of anthropogenic ammonia emissions in Asia, Atmos. Environ, 28, 689-694, 1994.

Estrellan, C. R. and Iino, F.: Toxic emissions from open burning, Chemosphere, 80, 193-207, 2010.

Galloway, J. N., Likens, G. E., Keene, W. C., and Miller, J. M.: The composition of precipitation in remote areas of the world, J. Geophys. Res.-Oceans (1978-2012), 87, 8771-8786, 1982.

Garcia, R., del Torres Ma, C., Padilla, H., Belmont, R., Azpra, E., Arcega-Cabrera, F., and Báez, A.: Measurement of chemical elements in rain from Rancho Viejo, a rural wooded area in the State of Mexico, Mexico, Atmos. Environ., 40, 6088-6100, 2006.

$\mathrm{Hu}, \mathrm{G}$. P. and Balasubramanian, R.: Wet deposition of trace metals in Singapore, Water Air Soil Pollut., 144, 285-300, 2003.
Huang, K., Zhuang, G., Xu, C., Wang, Y., and Tang, A.: The chemistry of the severe acidic precipitation in Shanghai, China, Atmos. Res, 89, 149-160, 2008.

Johnstone, R. A. W. and Plimmer, J. R.: The Chemical Constituents of Tobacco and Tobacco Smoke, Chem. Rev., 59, 885-936, 1959.

Jung, G. B., Kim, M. K., Lee, J. S., Kim, W. I., Kim, G. Y., and Ko, B. G.: Wet Deposition of Heavy Metals during Farming Season in Taean, Korea, Korean J. Environ. Agric., 30,153-159, 2011.

Kang, G. G., Collett, J. L., Shin, D. Y., Fujita, S. I., and Kim, H. K.: Comparison of the chemical composition of precipitation on the western and eastern coasts of Korea, Water Air Soil Pollut., 151, 11-34, 2004.

Kawamura, K. and Kaplan, I. R., Organic compounds in the rainwater of Los Angeles, Environ. Sci. Technol., 17, 497-501, 1983.

Kawamura, K. and Kaplan, I. R.: Biogenic and anthropogenic organic compounds in rain and snow samples collected in southern California, Atmos. Environ. (1967), 20, 115-124, 1986.

Kawamura, K. and Kaplan, I. R.: Motor exhaust emissions as a primary source for dicarboxylic acids in Los Angeles ambient air, Environ. Sci. Technol., 21, 105-110, 1987.

Kawamura, K., Steinberg, S., Ng, L., and Kaplan, I. R.: Wet deposition of low molecular weight mono-and di-carboxylic acids, aldehydes and inorganic species in Los Angeles, Atmos. Environ., 35, 3917-3926, 2001.

Kaya, G. and Tuncel, G.: Trace element and major ion composition of wet and dry deposition in Ankara, Turkey, Atmos. Environ., 31, 3985-3998, 1997.

Keene, W. C. and Galloway, J. N.: Organic acidity in precipitation of North America, Atmos. Environ. (1967), 18, 2491-2497, 1984.

Kieber, R. J., Peake, B., Willey, J. D., and Avery, G. B.: Dissolved organic carbon and organic acids in coastal New Zealand rainwater, Atmos. Environ., 36, 3557-3563, 2002.

Kim, J. E., Han, Y. J., Kim, P. R., and Holsen, T. M.: Factors influencing atmospheric wet deposition of trace elements in rural Korea, Atmos. Res., 116, 185-194, 2012.

Klouda, G. A, Lewis, C. W., Rasmussen, R. A., Rhoderik, G. C, Sams, R. L., Stevens, R. K., Currie, L. A., Donahue, D. J., Jull, A. J. T., and Seila, R. L.: Radiocarbon measurements of atmospheric volatile organic compound: quantifying the biogenic contribution, Environ. Sci. Technol., 30, 1098-1105, 1996.

Laniewski, K., Borén, H., Grimvall, A., and Ekelund, M.: Pyrolysis-gas chromatography of chloroorganic compounds in precipitation, J. Chromatogr. A, 826, 201-210, 1998.

Lara, L. B. L. S., Artaxo, P., Martinelli, L. A., Victoria, R. L., Camargo, P. B., Krusche, A., and Ballester, M. V.: Chemical composition of rainwater and anthropogenic influences in the Piracicaba River Basin, Southeast Brazil, Atmos. Environ., 35, 4937-4945, 2001.

Lee, B. K., Hong, S. H., and Lee, D. S.: Chemical composition of precipitation and wet deposition of major ions on the Korean peninsula, Atmos. Environ., 34, 563-575, 2000.

Leenher, J. A. and Croue, J. P.: Characterizing aquatic dissolved organic matter, Environ. Sci. Technol., 37, 18-26, 2003.

Lemieux, P. M., Lutes, C. C., and Santoianni, D. A.: Emissions of organic air toxics from open burning: a comprehensive review, Prog. Energ. Combust., 30, 1-32, 2004.

Lunde, G., Gether, J., Gjùs, N., and Stùbet Lande, M. B.: Organic micropollutants in precipitation in Norway, Atmos. Environ., 11, 1007-1014, 1977. 
Moon, S. H., Lee, J. Y., Lee, B. J., Park, K. H., and Jo, Y. J.: Quality of harvested rainwater in artificial recharge site on Jeju volcanic island, Korea, J. Hydrol., 414, 268-277, 2012.

Mouli, P., Mohan, S., and Reddy, S.: Rainwater chemistry at a regional representative urban site: influence of terrestrial sources on ionic composition, Atmos. Environ., 39, 999-1008, 2005.

Muller, C. L., Baker, A., Hutchinson, R., Fairchild, I. J., and Kidd, C.: Analysis of rainwater dissolved organic carbon compounds using fluorescence spectrophotometry, Atmos. Environ., 42, 8036-8045, 2008.

Pan, Y., Wang, Y., Xin, J., Tang, G., Song, T., Wang, Y. H., Li, X. R., Wu, F. K.: Study on dissolved organic carbon in precipitation in Northern China, Atmos. Environ., 44, 2350-2357, 2010.

Panyakapo, M. and Onchang, R.: A four-year investigation on wet deposition in western Thailand, J. Environ. Sci. (China), 20, 441448, 2008.

Peña, R. M., García, S., Herrero, C., Losada, M., Vázquez, A., and Lucas, T.: Organic acids and aldehydes in rainwater in a northwest region of Spain, Atmos. Environ., 36, 5277-5288, 2002.

Pike, S. M. and Moran, S. B.: Trace elements in aerosol and precipitation at New Castle, NH, USA, Atmos. Environ., 35, 33613366, 2001.

Rogge, W. F., Hildemann, L. M., Mazurek, M. A., Cass, G. R., and Simoneit, B. R. T.: Sources of fine organic aerosol: 1. Charbroilers and meat cooking operations, Environ. Sci. Technol., 25, 1112-1125, 1991.

Sakugawa, H., Kaplan, R., and Shepard, L.: Measurements of $\mathrm{H}_{2} \mathrm{O}_{2}$, aldehydes and organic acids in Los Angeles rainwater: their sources and deposition rates, Atmos. Environ. B, 27, 203219, 1993.

Santos, P. S., Otero, M., Duarte, R. M., and Duarte, A. C.: Spectroscopic characterization of dissolved organic matter isolated from rainwater, Chemosphere, 74, 1053-1061, 2009.

Santos, P. S, Otero, M., Santos, E. B., and Duarte, A. C.: Chemical composition of rainwater at a coastal town on the southwest of Europe: What changes in 20years?, Sci. Total. Environ, 409, 3548-3553, 2011.

Sato, E., Matsumoto, K., Okochi, H., and Igawa, M.: Scavenging effect of precipitation on volatile organic compounds in ambient atmosphere, Bull. Chem. Soc. Jpn., 79, 1231-1233, 2006.
Saxena, A., Kulshrestha, U. C., Kumar, N., Kumari, K. M., and Srivastava, S. S.: Characterization of precipitation at Agra, Atmos. Environ., 30, 3405-3412, 1996.

Seinfeld, J. H.: Atmospheric Chemistry and Physics of Air Pollution, Wiley, New York, 1986.

Seitzinger, S. P., Styles, R. M., Lauck, R., and Mazurek, M. A.: Atmospheric pressure mass spectrometry: a new analytical chemical characterization method for dissolved organic matter in rainwater, Environ. Sci. Technol., 37, 131-137, 2003.

Sigsby, J. E., Tejada, S., Ray, W., Lang, J. M., and Duncan, J. W.: Volatile organic compound emissions from 46 in-use passenger cars, Environ. Sci. Technol., 21, 466-475, 1987.

Simoneit, B. R. T.: Application of Molecular Marker Analysis to Vehicular Exhaust for Source Reconciliations, Int. J. Environ. Anal. Chem., 22, 203-233, 1985.

Wang, S., Wei, W., Du, L., Li, G., and Hao, J.: Characteristics of gaseous pollutants from biofuel-stoves in rural China, Atmos. Environ., 43, 4148-4154, 2009.

Wedepohl, H. K.: The composition of the continental crust, Geochim. Cosmochim. Acta, 59, 1217-1232, 1995.

Willey, J. D., Kieber, R. J., Eyman, M. S., and Avery Jr., G. B.: Rainwater dissolved organic carbon: concentrations and global flux, Global Biogeochem. Cy., 14, 139-148, 2000.

Wong, C. S. C., Li, X. D., Zhang, G., Qi, S. H., and Peng, X. Z.: Atmospheric depositions of heavy metals in the Pearl River Delta, China, Atmos. Environ., 37, 767-776, 2003.

Xu, T., Song, Z., Liu, J., Wang, C., Wei, J., and Chen, H.: Organic composition in the dry season rainwater of Guangzhou, China, Environ. Geochem. Health, 30, 53-65, 2008.

Yan, G. and Kim, G.: Dissolved organic carbon in the precipitation of Seoul, Korea: Implications for global wet depositional flux of fossil-fuel derived organic carbon, Atmos. Environ., 59, 117 124, 2012.

Zhao, M., Li, L., Liu, Z., Chen, B., Huang, J., Cai, J., and Deng, S.: Chemical Composition and Sources of Rainwater Collected at a Semi-Rural Site in Ya'an, Southwestern China, Atmos. Clim. Sci., 3, 486-496, 2013. 